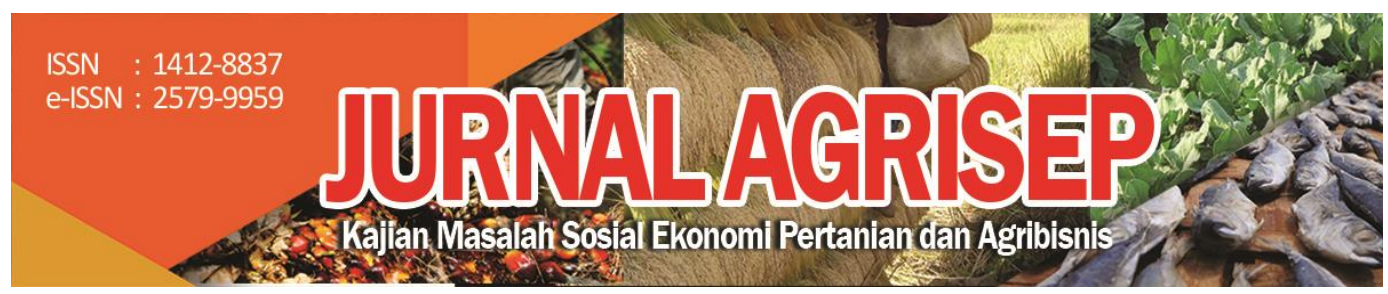

DOI: 10.31186/jagrisep.19.1.53-67

\title{
PENGUATAN SISTEM PENDIDIKAN SDM DALAM PEMBANGUNAN PERTANIAN: AGRIBISNIS DI MATA PEMUDA
}

\author{
Strengthening the Human Resources Education System in Agricultural \\ Development: Agribusiness in Youth Perspective
}

\author{
1)Kadhung Prayoga ${ }^{凶}$; ${ }^{2)}$ Suryani Nurfadillah; 3) Adietya Muhammad Riezky \\ 1),2),3) Agribisnis, Departemen Pertanian, Fakultas Peternakan dan Pertanian, \\ Universitas Diponegoro \\ Email: kadhungprayoga@gmail.com
}

\begin{abstract}
The interest of students to continuing their study into university level is very high, one of which is the department of agribusiness. This certainly contradicts with the low interest of young people to become farmers. Because of this phenomena, then this paper want to discuss how students' knowledge, judgment, and perceptions of agribusiness as they were high school students and as college students now. This research used descriptive method with a quantitative approach and survey as its research technique. The samples for this study were 48 new students of 2018 Agribusiness Program, Faculty of Animal and Agricultural Sciences, Diponegoro University that taken by convenience sampling. Primary data was obtained by distributing questionnaires using google form on December 9-22, 2018. While secondary data was obtained from literature studies. The collected data was then analyzed descriptively. The majority of respondents have minimal knowledge regarding agribusiness program when they were in high school, some even did not know at all. They can only perceive agribusiness as a study program related to business and economic in agriculture. The majority of respondents chose agribusiness just for trying their luck, but there were also those based on desire, passion, opportunities, and parents' advises. After becoming a Agribusiness student, they saw agribusiness as an attractive department because it combines natural and social science. Massive socialization is needed to increase public understanding and interest in agribusiness program.
\end{abstract}

Key Word: agribusiness, knowledge, new students, perception 


\begin{abstract}
ABSTRAK
Animo pelajar untuk bisa melanjutkan pendidikan ke tingkat perguruan tinggi saat ini sangatlah tinggi, salah satunya adalah program studi agribisnis. Hal ini tentu bertolak belakang dengan rendahnya minat pemuda untuk menjadi petani. Inilah yang kemudian melatarbelakangi penulisan paper ini untuk membahas tentang bagaimana pengetahuan, penilaian, dan persepsi pemuda terhadap agribisnis saat masih menjadi siswa SMA maupun ketika sudah menjadi mahasiswa. Penelitian ini bersifat deskriptif dengan pendekatan kuantitatif. Teknik penelitiannya menggunakan survei. Sampel dari penelitian ini adalah 48 mahasiswa baru angkatan 2018 Program Studi Agribisnis, Fakultas Peternakan dan Pertanian, Universitas Diponegoro yang diambil dengan teknik convenience sampling. Data primer didapatkan dengan menyebarkan kuesioner (google form) pada tanggal 9-22 Desember 2018. Sedangkan data sekunder didapatkan dari studi pustaka. Data yang terkumpul kemudian dianalisis secara deskriptif. Mayoritas responden memiliki pengetahuan yang minim terkait program studi agribisnis ketika masih SMA, bahkan ada yang tidak tahu sama sekali. Mereka hanya bisa mempersepsikan agribisnis sebagai program studi yang berkaitan dengan bisnis dan tata kelola ekonomi di bidang pertanian. Sebagian besar responden memilih agribisnis hanya karena coba-coba, namun ada pula yang berdasarkan keinginan, passion, peluang diterima yang besar, dan dukungan dari orang tua. Setelah menjadi mahasiswa, responden memandang agribisnis sebagai program studi yang menarik karena memadukan berbagai macam disiplin ilmu secara bersamaan, yaitu sosial dan alam. Untuk meningkatkan pemahaman dan animo masyarakat terhadap program studi agribisnis sudah saatnya dilakukan sosialisasi secara massif.
\end{abstract}

Kata Kunci: agribisnis, mahasiswa baru, pengetahuan, persepsi

\title{
PENDAHULUAN
}

Pembangunan suatu negara sangat erat kaitannya dengan kesiapan sumber daya manusia yang dimiliki untuk bersaing di pasar global, termasuk Indonesia. Merunut data dari BPS (2017) jumlah pemuda di Indonesia mencapai 63,36 juta jiwa atau setara dengan 24,27\% dari total penduduk. Bonus demografis ini ternyata tidak diikuti dengan kualitas sumber daya manusia yang mumpuni. Dilansir dari UNDP (2018) kualitas sumber daya manusia di Indonesia masih masuk dalam kategori medium. Indonesia hanya berada di posisi 116 dari 169 negara yang ada. Angka ini menyiratkan bahwa Indonesia akan susah berkompetisi dengan negara lain dan tidak bisa mengambil manfaat sebesar-besarnya dari globalisasi. Salah satu jalan yang harus diambil adalah memberikan peluang yang besar ke pemuda untuk mengenyam pendidikan di perguruan tinggi. Kharisma dan Latifah (2015) juga mendorong untuk meningkatkan minat pemuda melanjutkan pendidikan ke perguruan tinggi karena akan memberikan kontribusi besar dalam menciptakan sumber 
daya manusia yang berkualitas dan memiliki berbagai keahlian yang mendalam.

Pendidikan diharapkan menjadi katalisator peningkatan mutu sumber daya manusia (Fitriani, 2014). Apabila suatu masyarakat di suatu negara memiliki tingkat pendidikan yang tinggi maka akan memudahkan mereka mengolah sumber daya alam yang dimiliki. Tingkat kesejahteraan masyarakatpun diharapkan akan meningkat. Senada dengan hal ini, Damianos (2008) dalam Koutsou dan Partalidou (2012) juga menjelaskan kualitas dari sumber daya manusia sangat tergantung kepada tingginya akses pendidikan dan kesempatan untuk mendapatkan pelatihan. Meskipun pendidikan memiliki peran yang sentral, namun menurut data dari BPS (2017) hanya 2 dari 10 pemuda dengan kelompok pengeluaran 20\% teratas yang mampu menamatkan studi di perguruan tinggi. Banyak faktor yang menyebabkan pemuda tidak melanjutkan studinya, utamanya adalah biaya pendidikan di perguruan tinggi yang semakin mahal. Orang tua lebih memilih mendorong anaknya untuk bekerja mencari uang demi pemasukan tambahan keluarga daripada harus melanjutkan studi ke perguruan tinggi.

Perguruan tinggi di Indonesia juga sudah sadar akan peran sentralnya dalam meningkatkan kualitas SDM. Berbagai upaya dilakukan pemerintah bersama pihak perguruan tinggi untuk meningkatkan minat pemuda agar bersedia melanjutkan studinya. Beberapa usaha itu adalah pemberian beasiswa bidik misi bagi anak-anak yang berasal dari keluarga tidak mampu, beasiswa bagi mereka yang berprestasi, hingga usaha pembukaan beragam program studi untuk mengakomodasi minat pemuda. Dari beragam program studi yang ada, salah satu program studi yang dibuka adalah agribisnis. Agribisnis lambat laun bahkan menjadi program studi yang cukup diminati karena prospek bisnis pangan kedepan yang masih cerah. Daya tarik inilah yang kemudian membuat banyak universitas membuka program studi ini. Setidaknya terdapat 198 program studi agribisnis yang tersebar di berbagai kampus di Indonesia.

Meskipun begitu, program studi agribisnis masihlah dipandang masyarakat sebagai program studi kasta kedua yang kurang memiliki prospek kerja. Senada dengan hal ini Hambali (2017) menyebutkan bahwa sektor pertanian dianggap tidak menjanjikan bagi para pekerja, sehingga harus dihindari. Akibatnya orang tua tidak bangga atau khawatir dengan masa depan anaknya ketika mereka berkuliah di program studi agribisnis. Pandangan yang negatif terhadap sektor pertanian masih menjadi penyebab kuncinya. Lebih lanjut, Budiati (2014) menjelaskan bahwa persepsi tentang kegiatan usaha tani dan nasib petani yang suram semakin mengukuhkan persepsi negatif masyarakat terhadap sektor pertanian.

Salah satu universitas yang memiliki program studi agribisnis adalah Universitas Diponegoro. Berada di bawah naungan Fakultas Peternakan dan Pertanian, program studi agribisnis memiliki peminat yang tergolong tinggi 
setiap tahunnya. Dilansir dari website SNMPTN (2018), untuk jalur SNMPTN di tahun 2014 hingga 2017 jumlah pendaftarnya berturut-turut adalah 1.006, $1.216,1.019$, dan 866 orang. Belum lagi para siswa yang memilih program studi agribisnis lewat jalur SBMPTN dan Ujian Mandiri. Menjadi menarik ketika banyak siswa SMA yang memilih berkuliah di program studi agribisnis dengan mengambil resiko serta stigma yang harus mereka terima dari masyarakat, bahkan keluarga. Apa yang dilakukan oleh pemuda untuk kuliah di program studi agribisnis juga bertentangan dengan temuan Rahmawatiningsih et. al. (2010) yang memperlihatkan suatu fenomena yaitu rendahnya minat pemuda melanjutkan kuliah di bidang pertanian.

Penelitian ini kemudian bertujuan untuk melihat pengetahuan dan pandangan atau persepsi para mahasiswa baru program studi agribisnis terhadap program studinya baik ketika masih menjadi siswa SMA maupun ketika sudah menjadi mahasiswa, termasuk didalamnya alasan kenapa mereka memilih program studi agribisnis. Penelitian ini menjadi menarik karena pada kenyataannya banyak mahasiswa baru di program studi agribisnis yang pada akhirnya putus di tengah jalan atau berpindah program studi. Program studi agribisnis terkadang hanya dijadikan sebagai batu loncatan semata.

\section{METODE PENELITIAN}

Merunut pada tujuannya, penelitian ini bersifat deskriptif dengan pendekatan kuantitatif. Teknik penelitiannya menggunakan survei. Survei merupakan studi yang bersifat kuantitatif yang digunakan untuk meneliti gejala suatu kelompok atau perilaku individu. Dalam penelitian ini adalah untuk mengetahui informasi secara sistematis terkait dengan pandangan atau persepsi para mahasiswa baru program studi agribisnis terhadap program studinya baik ketika masih menjadi siswa SMA maupun ketika sudah menjadi mahasiswa. Jumlah sampel pada penelitian ini sebanyak 48 orang yang didapatkan dengan metode convenience sampling (non probability sampling). Sampel dipilih secara acak dengan menyebar kuesioner secara online dan melihat berapa banyak sampel yang mengembalikan kuesioner tersebut. Convenience dipilih karena murah, tidak menghabiskan waktu, serta kemudahan akses kepada sampel sehingga mudah didekati dan didapatkan.

Pada penelitian ini, data yang digunakan ada dua yaitu data primer dan sumber data sekunder. Data primer didapatkan dengan menyebarkan kuesioner (google form) kepada seluruh populasi dalam jangka waktu 2 minggu, mulai tanggal 9-22 Desember 2018. Sedangkan data sekunder didapatkan dari studi pustaka. Data yang terkumpul kemudian dianalisis secara deskriptif untuk menghasilkan gambaran dari data yang telah terkumpul berdasarkan jawaban responden.

56 | Kadhung P; Suryani N; Adietya Muhammad; Penguatan Sistem... 


\section{HASIL DAN PEMBAHASAN}

Bonus demografis tengah dinikmati oleh Indonesia, bahkan diramalkan tahun 2045 akan menjadi tahun keemasan karena banyaknya jumlah pemuda yang dimiliki. Diharapkan pula pemuda ini bisa berperan aktif dalam pembangunan sektor pertanian di Indonesia karena menurut Toor (1991) populasi yang mayoritas diisi anak muda adalah segmen yang paling penting dalam suatu komunitas pertanian. Namun, kenyataannya adalah sangat kecil dari mereka yang tertarik berkarir di sektor pertanian (Mukembo et.al., 2014). Antitesis ini jika dirunut berdasarkan penelitian Kruijssen (2009) dalam Mukembo et. al. (2015) terjadi karena kurangnya informasi dan penyuluhan terkait kesempatan dan prospek berkarir di sektor pertanian. Berk (2018) bahkan sudah mengingatkan bahwa hal ini akan berakibat pada hilangnya komunitas perdesaan, lebih lanjut keberlanjutan penyediaan pangan di suatu negara akan terganggu.

Menurunnya minat pemuda yang tertarik ke sektor pertanian tidak hanya kondisi yang umum ditemui di Indonesia. Negara besar di Asia Tenggara dan Eropa yang hidup di sektor pertanianpun mengalaminya. Thailand sebagai negara yang terkenal dengan hasil buminyapun tak luput dari fenomena ageing farmers yang menyebabkan hilangnya budaya agraris (Oizumi, 2013; Rigg et. al., 2012 dan Ariyapruchya et. al., 2016). Di India, merujuk pada Sainath (2013) dalam Banu dan Yashoda (2018) bahkan menyebutkan telah hilangnya 15.000 petani sejak tahun 1991 sampai tahun 2018. Tidak hanya di Asia Tenggara, European Union telah menghadapi dua masalah utama di sektor pertanian yaitu langkanya petani muda dan tingginya populasi petani tua. Di Yunani, Ceko dan Turki keberlanjutan sektor pertanian terancam karena kondisi kekurangan petani baru akibat dari kebijakan yang kurang menguntungkan (Kontogeorgos et. al., 2014; Simpach dan Pechrova, 2014; Kan et. al., 2018). Semua ini terjadi karena adanya pandangan bahwa bekerja di sektor pertanian tidaklah memberi keuntungan.

Untuk meningkatkan lagi gairah pemuda terhadap sektor pertanian maka program studi agribisnis bisa menjadi pilihan ketika pemuda akan melanjutkan pendidikan ke tingkat perguruan tinggi. Daya tawar yang memadukan konsep pertanian secara on farm dan bagaimana mengelola bisnisnya diharapkan mampu memancing pemuda untuk mencintai sektor pertanian. Agribisnis menjadi sentral ketika dalam suatu kegiatan pembangunan pertanian membutuhkan kesiapan sumber daya manusia, cara pandang bisnis baru di bidang pertanian, dan bagaimana membuat suatu kebijakan yang menguntungkan bagi petani.

\section{Pengetahuan dan Persepsi Pemuda terkait Program Studi Agribisnis}

Responden dalam penelitian ini adalah mahasiswa baru Program Studi Agribisnis, Fakultas Peternakan dan Pertanian, Universitas Diponegoro tahun 
2018. Sejumlah 48 responden terdiri dari 10 laki-laki dan 38 perempuan dengan rentang umur 18-19 tahun. Menarik untuk dilihat bahwasanya ternyata mahasiswa program studi agribisnis yang notabene berada di bawah Departemen Pertanian justru lebih diminati oleh siswa yang berjenis kelamin perempuan. Pertanian yang dahulu selalu identik dengan laki-laki ternyata kini mulai berubah. Terjadi pergeseran yang sangat signifikan karena justru mahasiswa agribisnis kini ternyata juga lebih didominasi oleh anak perempuan. Hasil survey yang di dapatkan juga menjelaskan suatu hal yang tidak sewajarnya bahwa ternyata banyak perempuan yang justru memilih kuliah di bidang pertanian.

Ketika masih di bangku SMA, mayoritas dari responden memiliki pengetahuan yang minim terkait program studi agribisnis. Sebanyak 39 responden $(81,25 \%)$ ketika masih duduk di bangku SMA hanya bisa mengartikan agribisnis sebagai program studi yang berkaitan dengan bisnis dan tata kelola ekonomi di bidang pertanian. Meskipun begitu responden mempersepsikan kuliah di agribisnis akan sangat menyenangkan karena mereka akan belajar pertanian, utamanya bisnisnya dan terbebas dari mata kuliah eksakta seperti fisika, kimia, dan biologi.

Ada juga dari mahasiswa yang sewaktu duduk dibangku SMA belum mengetahui tentang program studi agribisnis itu seperti apa. Total masih ditemui 5 orang $(10,42 \%)$ yang tidak tahu apa itu agribisnis. Persepsi mereka terhadap agribisnis juga negatif, kurang menarik dan biasa saja itulah dua hal yang mereka pikirkan terkait program studi agribisnis. Responden hanya cenderung melihat peluang diterima yang tinggi dan ikut saja dengan pilihan temannya. Alasan inilah yang kemudian bisa dipahami kenapa pada kemudian hari banyak dari mereka yang keluar atau pindah program studi. Tidak hanya itu, 4 orang responden $(8,33 \%)$ bahkan memiliki jawaban yang tidak sesuai dengan pengertian agribisnis itu sendiri. Beberapa responden mengira bahwa agribisnis adalah program studi yang didalamnya berkaitan dengan pengolahan produk pertanian. Ternyata dapat dilihat bahwa masih banyak pengertian yang salah maupun keliru terkait agribisnis di benak pemuda.

Mayoritas dari responden tidak mengira jika mereka juga akan mempelajari pertanian itu sendiri (secara on farm di lahan). Agribisnis hanya diartikan pertanian di bidang hilir saja, belum sampai ke bagian hulu. Anggapan yang menitikberatkan agribisnis hanya terkait manajemen bisnisnya tentu menimbulkan penilaian yang berbeda dengan ekspektasi. Penilaian negatifpun muncul dari mereka yaitu sebesar $50 \%$ responden. Hal ini terjadi karena dalam kurikulum yang ada di Program Studi Agribisnis masih ada mata kuliah seperti kimia dan fisika, yang mana menurut mereka mata kuliah ini tidak terlalu dibutuhkan.

Meskipun begitu, ada juga responden yang sudah secara spesifik mendefinisikan agribisnis sebagai sebuah sistem dari hulu hingga hilir yang 
saling terintegrasi, mulai dari pemilihan input, penguatan kualitas sumber daya petani, teknologi budidaya, pemanenan, penanganan pasca panen, hingga pemasarannya. Adapula yang mengartikan agribisnis merupakan disiplin ilmu yang mempelajari tentang bagaimana mengelola, mengatur, dan memanajemen suatu usaha atau bisnis di bidang pertanian. Mereka yang dari awal sudah memegang definisi ini sebelum memilih berkuliah di agribisnis merasa tidak kecewa dan bahkan memberikan penilaian positif karena ekspektasi mereka sudah sesuai dengan apa yang didapatkan.

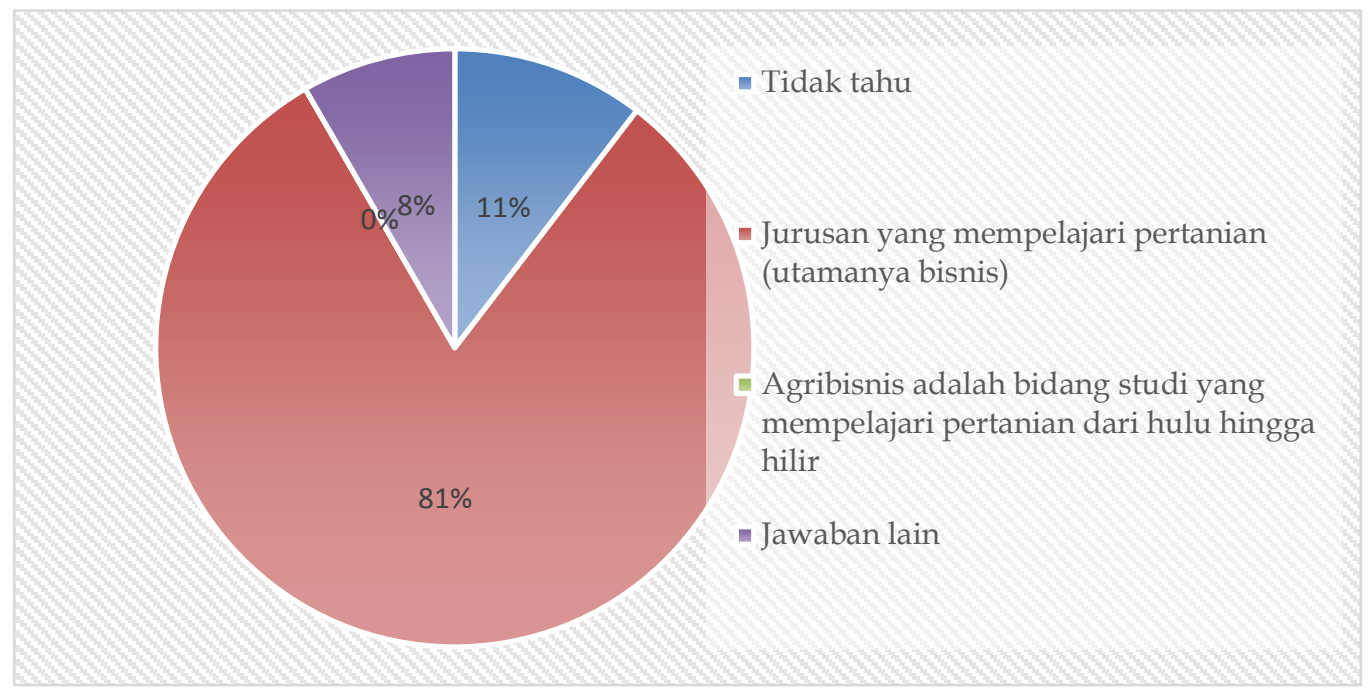

Gambar 1.

\section{Pengetahuan Responden Ketika Masih SMA terhadap Program Studi Agribisnis}

Kurangnya pengetahuan responden terkait program studi agribisnis bisa jadi dikarenakan banyak hal, utamanya yaitu kurangnya sosialisasi terkait program studi agribisnis kepada siswa SMA. Guru SMA memiliki keterbatasan terkait gambaran mengenai perkuliahan di program studi agribisnis. Sementara itu, informasi di internet juga masih sederhana, sehingga tidak mengherankan jika pengetahuan siswa SMA terkait program studi agribisnis juga masih minim. Selain dari internet dan guru Sma, pengetahuan terkait program studi agribisnis didapatkan responden dari beragam sumber, seperti yang ditunjukkan oleh Gambar 2. 


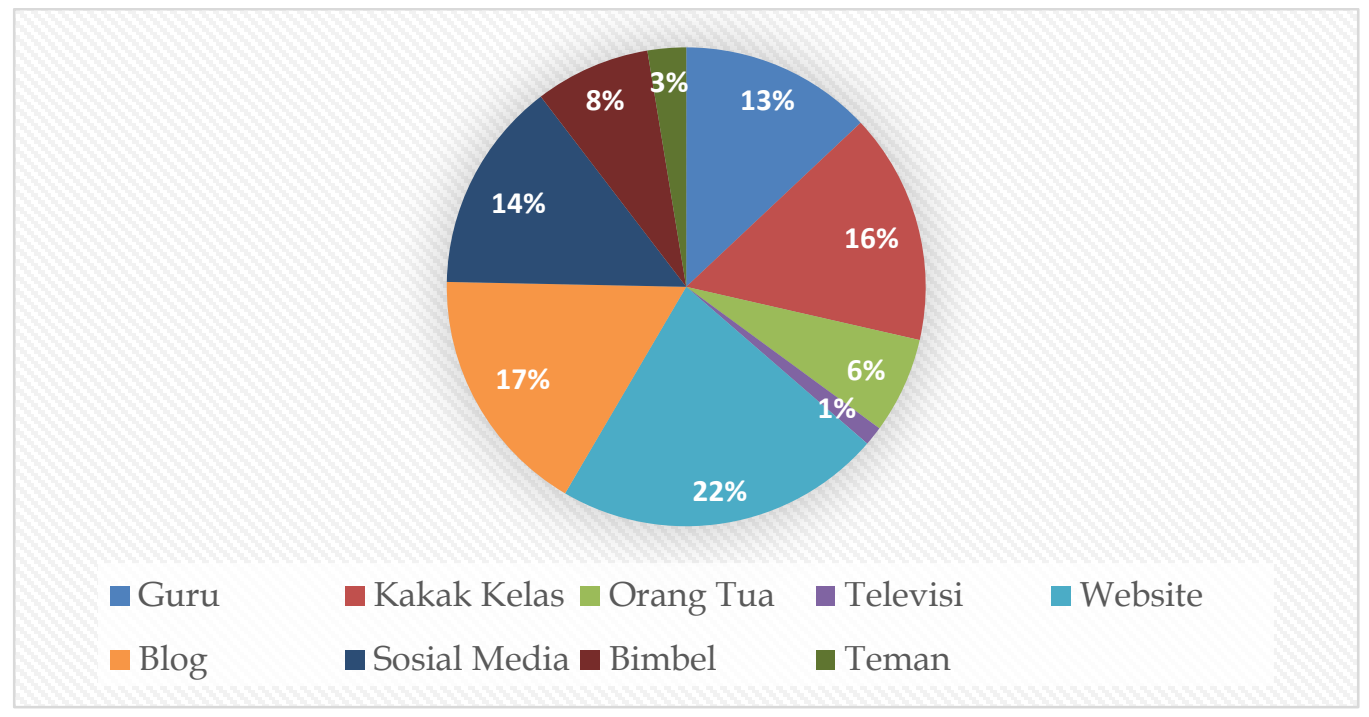

\section{Gambar 2. \\ Sumber Informasi Terkait Program Studi Agribisnis}

Responden mengaku mereka tidak hanya mendapatkan informasi mengenai agribisnis hanya dari satu sumber saja. Sewaktu duduk dibangku SMA, banyak responden yang ternyata juga mendapatkan informasi dari kakak kelasnya ketika SMA. Kegiatan-kegiatan yang dilakukan kakak tingkat untuk mensosialisasikan kampus dan program studi menjadi salah satu sumber informasi untuk mengenal agribisnis lebih dekat. Teman juga menjadi salah satu sumber responden ketika mencari informasi mengenai agribisnis. Selain itu, mereka juga mendapatkan informasi dari televisi dan tempat bimbingan belajar. Banyaknya sumber informasi ini mengindikasikan mudahnya informasi terkait perkuliahan di program studi agribisnis.

Sebanyak $77,1 \%$ responden mengaku informasi terkait perkuliahan di program studi agribisnis sangat mudah ditemukan, namun masih terdapat 22,9 $\%$ responden yang mengaku sebaliknya. Meskipun informasi mudah didapat ternyata hal ini berbanding terbalik dengan pengetahun dan pemahaman mereka terkait agribisnis. Hal ini terjadi karena mungkin informasinya kurang detail dan informatif sehingga pengetahuan calon mahasiswapun menjadi kurang dalam. Kemudahan mendapatkan informasi ini ternyata berbanding lurus dengan keputusan mereka ketika akan memilih program studi agribisnis. Sebanyak 81,3\% jawaban responden menjelaskan bahwa kemudahan informasi terkait agribisnis ikut mempengaruhi mereka ketika akan memilih program studi saat kuliah.

Uniknya, dalam kasus ini responden justru tidak banyak mendapatkan informasi mengenai program studi dari perguruan tinggi selaku penyedia jasa. Responden lebih banyak mengandalkan kelompok rujukan untuk 
mendapatkan informasi. Kelompok rujukan itu termasuk didalamnya teman, orang tua, dan guru. Penelitian Nalim (2012), Kharisma dan Latifah (2015), serta Birama dan Nurkhin (2017) juga menunjukkan suatu fakta bahwasanya keputusan untuk memilih program studi banyak dipengaruhi oleh rekomendasi teman atau keluarga.

\section{Alasan Memilih Program Studi Agribisnis}

Terdapat banyak alasan yang melandasai seorang siswa ketika akan memilih program studi agribisnis sebaga pilihan kuliahnya. Dari yang pada awalnya hanya coba-coba hingga karena memang memiliki ketertarikan untuk terjun di sektor pertanian. Seperti Purnamasari dan Hayati (2018) yang menyebutkan setidaknya terdapat 6 faktor yang mempengaruhi seseorang ketika akan memilih universitas atau program studi yaitu dukungan kelurga, dukungan masyarakat sekitar tempat tinggal, pandangan masyarakat sekitar terhadap pendidikan, dukungan sekolah (guru dan teman), umur, serta kemudahan memperoleh informasi baik terkait perguruan tinggi maupun beasiswa yang bisa diperoleh.

Secara rinci responden menjelaskan bahwa program studi agribisnis masih belum banyak yang melirik, sehingga kesempatan untuk diterima tentu menjadi lebih besar. Mayoritas responden yaitu sebanyak $64,6 \%$ mengaku memilih agribisnis karena peluang masuknya yang besar. Apalagi program studi masih belum terlalu populer dibandingkan program studi yang lain seperti teknik atau kedokteran. Pertimbangan lainnya adalah passing grade yang rendah dan mayoritas hanya memilih program studi agribisnis pada pilihan ketiga, sehingga kemudian mereka menjadikan agribisnis sebagai pilihan pertama agar lebih diprioritaskan. Namun, yang justru terjadi selanjutnya adalah rasa percaya diri mereka turun karena mereka merasa tidak ada gengsinya ketika kuliah di agribisnis. Sebanyak $72,9 \%$ responden mengaku agribisnis bukanlah program studi yang bergengsi dan cenderung dipandang sebelah mata.

Peran dan dukungan keluarga juga menjadi penting karena ada pula responden yang memilih agribisnis karena kakaknya kuliah di agribisnis juga atau orang tuanya yang berkarir di sektor pertanian. Orang tua yang bekerja di sektor pertanian memiliki kecenderungan untuk mengarahkan anaknya kuliah di agribisnis karena mereka mengetahui peluang kedepannya. Seperti temuan Shanka et. al. (2005) dan Koech et. al. (2016) juga menunjukkan bahwa faktor dukungan keluarga dan teman-teman merupakan faktor yang signifikan dalam menentukan pilihan karir seperti memilih universitas atau pekerjaan. Orang tua menjadi rujukan utama karena menurut Indriyanti et. al. (2013) hal ini dipengaruhi oleh pendapatan, pendidikan, dan dorongan orang tua. Anak cenderung akan melihat 3 hal itu sebelum memilih program studi karena orang tua merupakan orang yang akan membiayai mereka. 
Di Fakultas Peternakan dan Pertanian, Universitas Diponegoro sendiri, uang SPP di program studi agribisnis adalah yang paling rendah. Responden merasa tidak ingin membebani orang tuanya sehingga agribisnis kemudian menjadi pilihan mereka. Senada dengan Nalim (2012), Ekpo dan Ajake (2013), Fitriani (2014), Kharisma dan Latifah (2015), Setiawan (2018), serta Mc Greevy et. al. (2018) yang menyebutkan bahwa status sosial ekonomi orang tua akan berpengaruh ketika anak ingin melanjutkan sekolahnya. Semakin murah biaya perkuliahan di suatu program studi, maka anak akan memeiliki kecenderungan untuk memilihnya. Disimpulkan bahwa biaya pendidikan bisa menjadi motivasi seseorang ketika memutuskan untuk melanjutkan pendidikan ke perguruan tinggi.

Namun, dari hasil survey yang di dapat, 93,8\% responden memilih agribisnis bukan karena pengaruh orang tua. Menurut responden orang tua lebih menyerahkan sepenuhnya pilihan program studi kepada anaknya. Orang tua hanya sekedar menyarankan dan mendampingi. Orang tua tidak dominan dalam menentukan program studi bagi anaknya karena ada suatu ketakutan anaknya akan salah program studi atau tidak suka jika dipilihkan yang berakibat pada si anak tidak bisa mengikuti perkuliahan dengan tenang dan nyaman bahkan tidak bisa memahami mata kuliahnya. Meskipun begitu, ada pula orang tua yang pada mulanya merasa berat jika anaknya harus kuliah di program studi agribisnis karena merasa prospek kerja yang kurang bagus di sektor pertanian. Hal ini bisa dipahami karena adanya stigma masyarakat yang masih negatif terhadap sektor pertanian.

Alasan unik lainnya juga dikemukakan responden yaitu mereka mengira bahwa kuliah di program studi agribisnis membuat mereka tidak akan bersinggungan dengan ilmu-ilmu alam seperti fisika, kimia, dan biologi. Mereka mengira bahwa agribisnis hanya akan mempelajari tentang manajemen dan ekonomi pertaniannya saja. Namun, ada juga yang berpikir sebaliknya justru daya tarik utama bagi calon mahasiswa adalah melihat agribisnis sebagai perpaduan antara ipa dan ips yang mempelajari keduanya secara bersamaan.

Tidak berhenti disitu, latar belakang wilayah dimana mereka tinggal juga menjadi salah satu pertimbangan. Responden merasa asal daerahnya yang notabene adalah kawasan pertanian menjadikan penggerak bagi mereka untuk memilih program studi agribisnis. Responden juga melihat jika kuliah di agribisnis maka kesempatan bekerja mereka bisa terbuka lebar, muali di sektor publik hingga menajdi wirausahawan. Penelitian-penelitian akhir-akhir ini juga menunjukkan trend yang demikian, dimana beriwausaha di sektor pertanian tengah naik daun. Bahkan menurut Hron et. al. (2009) dan Verhees et. al. (2011) perkembangan bisnis dunia saaat ini bergerak ke bidang pertanian. Kan et. al. (2018) dalam studinya bahkan dengan jelas merekomendasikan agar mengedukasi pemuda dengan sistem pendidikan formal yang dipadukan dengan semangat berwirausaha yang tinggi agar para pemuda tetap mau 
bergerak di bidang pertanian. Meskipun begitu, mengenaskan ketika ternyata tidak ada satupun responden yang memiliki keinginan untuk menjadi petani.

\section{Perubahan Persepsi Terhadap Program Studi Agribisnis}

Setelah menjadi bagian dari program studi agribisnis, para responden menilai agribisnis merupakan program studi yang menarik karena memadukan ilmu alam dan ilmu sosial ekonomi secara bersamaan. Apalagi notabene mereka adalah lulusan SMA dengan peminatan ilmu alam sehingga saat SMA mereka tidak mendapatkan pelajaran yang mendalam terkait bidang sosial ekonomi. Agribisnis juga sedikit mengejutkan bagi beberapa responden karena di awal mereka mengira agribisnis hanya akan berbicara tentang bisnis dan ekonomi saja. Ternyata agribisnis juga mempelajari pertanian secara luas mulai dari hulu hingga hilir, mulai dari penanaman hingga pemanenan. Kompleksitas inilah yang menurut mereka menjadikan agribisnis menarik untuk dipelajari, bahkan belum pernah mereka temui sebelumnya.

Penilaian mereka terhadap program studi agribisnis juga terkait dengan banyaknya kegiatan praktikum yang dilakukan. Di awal mereka mengira tidak akan ada praktikum, tapi ternyata praktikum justru menjadi bagian yang tidak terpisahkan dengan perkuliahan. Namun, hal ini justru menantang bagi sebagian responden karena dengan praktikum mereka bisa mengaplikasikan secara langsung teori yang mereka dapatkan di kelas. Mereka mengaku bahwa praktikum ternyata bisa menambah pengetahuan mereka terkait pertanian. Manfaat lainnya adalah dari yang awalnya tidak tahu jurnal, sitasi, dan laporan kini mereka sudah terbiasa dengan istilah akademik seperti itu. Agribisnis tentu tidaklah sesederhana yang mereka bayangkan sebelum memulai perkuliahan.

Banyak komentar positif mengenai penilaian program studi agribisnis dari responden selama menjalani satu semester kegiatan perkuliahan. Mahasiswa merasa senang dan bangga pada saat mereka mempelajari tentang agribisnis. Jadi, secara umum penilaian mereka terhadap agribisnis adalah menyenangkan, menantang, dan sudah sesuai dengan ekspektasi mereka. Namun, meskipun banyak penilaian positif yang diberikan ada juga yang menilai agribisnis sebaliknya. Mereka menilai agribisnis kurang begitu menarik karena ada beberapa mata kuliah yang kurang memiliki korelasi dengan agribisnis itu sendiri, seperti kimia dan fisika. Ada pula responden yang memandang agribisnis adalah program studi yang sulit karena mempelajari banyak hal. Hal ini terkadang membuat beberapa responden merasa tidak excited.

Dari beragam penilaian ini, dapat disimpulkan bahwa sebesar 66,7\% responden menilai berkuliah di agribisnis sudah sesuai dengan apa yang mereka inginkan selama ini. Sementara itu, sebanyak 8,3\% responden memberikan jawaban tidak ketika ditanya apakah kuliah di agribisnis sudah 
sesuai dengan apa yang mereka inginkan. Ini pulalah yang kemudian melahirkan penilaian negatif terhadap agribisnis karena tidak sesuai dengan apa yang mereka bayangkan sebelumnya. Sisanya sebesar 25\% masih merasa ragu-ragu karena belum lama berkuliah. Responden yang masih ragu-ragu ini berusaha menyesuaikan diri untuk mengikuti perkuliahan di agribisnis karena tidak semua mahasiswa agribisnis memilih program studi ini karena keinginan sendiri. Ketertarikan mereka juga masih rendah karena mereka masuk ke agribisnis ada yang karena pilihan ketiga, pilihan orang tua, dan tidak tahu mau memilih apa sebelumnya. Setelah didalami bahkan dari $25 \%$ responden yang mengaku ragu-ragu tersebut, setidaknya $41,7 \%$ diantaranya mengaku sebenarnya bingung mau memilih program studi apa ketika kuliah.

Keraguan inilah yang kemudian memunculkan niat dari responden untuk mengikuti tes seleksi masuk perguruan tinggi lagi. Sebanyak 29,2\% responden mengaku akan mengikuti proses seleksi masuk perguruan tinggi lagi. Alasan mereka beragam, mulai dari yang belum puas dengan apa yang sudah mereka dapatkan, belum sesuai keinginan, tidak sesuai passion, belum merasa nyaman dan sesuai, dorongan dari orang tua untuk ikut seleksi lagi, mencoba peruntungan, hingga ingin mengetahui batas kemampuannya. Sesuai dengan penelitian Daharnis dan Ardi (2016) yang menjelaskan bahwa kondisi ketidakcocokan tersebut akan membawa pengaruh terhadap kondisi aktivitas belajar mahasiswa. Bisa dilihat bahwa keraguan yang muncul dari para responden terjadi karena adanya missmatch antara informasi yang didapatkan dengan realita yang sesungguhnya. Kemungkinan lain adalah adanya kekeliruan informasi mengenai program studi yang akan dipilih.

\section{SIMPULAN DAN SARAN}

\section{Simpulan}

Mayoritas dari responden memiliki pengetahuan yang minim terkait program studi agribisnis ketika masih SMA, bahkan ada yang tidak tahu sama sekali. Mereka hanya bisa mengartikan agribisnis sebagai program studi yang berkaitan dengan bisnis di sektor pertanian. Minimnya pengetahuan terkait program studi agribisnis dikarenakan banyak hal, utamanya yaitu kurangnya sosialisasi terkait program studi agribisnis kepada siswa SMA. Akibatnya banyak mahasiswa yang merasa salah program studi dan ingin mengikuti seleksi masuk perguruan tinggi lagi. Mayoritas terjadi pada mereka yang memilih agribisnis hanya karena coba-coba. Sementara itu, ada juga yang memilih agribisnis karena memang keinginan, passion, peluang diterima yang besar, dan ada dukungan dari orang tua. Namun, setelah menjadi mahasiswa, responden memandang agribisnis sebagai program studi yang menarik karena memadukan berbagai macam disiplin ilmu secara bersamaan. Responden juga 
terkejut karena agribisnis tidak hanya berbicara tentang manajemen atau ekonomi saja, namun juga terkait ilmu alam, komunikasi, dan penyuluhan.

\section{Saran}

Untuk meningkatkan pemahaman dan animo masyarakat terhadap program studi agribisnis sudah saatnya dilakukan sosialisasi secara massif. Sosialisasi tidak hanya diberikan kepada mahasiswa ketika sudah masuk saja, namun pengelola program studi juga harus menjemput bola dengan mendatangi sekolah-sekolah untuk mengenalkan apa itu agribisnis. Bekerjasama dengan bimbel ataupun menugaskan mahasiswa agribisnis untuk sosialisasi kepada adik tingkatnya juga merupakan opsi yang bisa dipilih. Disamping itu, pemanfaatan media untuk sosialisasi juga perlu ditingkatkan, media televisi dan media sosial bisa menjadi pilihan karena mampu menjangkau masyarakat luas.

\section{DAFTAR PUSTAKA}

Ariyapruchya, K., Martin, S., Eduardo, M., Reungsri, T., and Luo, X. 2016. Thailand Economic Monitor. Washington DC: World Bank.

Badan Pusat Statistik. 2017. Statistik Pemuda Indonesia 2017. http://www.bps.go.id/publication/2018/04/13/040941963dd0c2fe89ffcee6/stati stik-pemuda-indonesia-2017.html. Diakses pada 17 Desember 2018.

Banu, N., and Yashoda, K. 2018. Empowering Young Farmers for Sustainable Agriculture. Journal of Pharmacognosy and Phytochemistry 7(3): 32913300.

Berk, A. 2018. Factors Affecting the Exit from Farming of Young Farmers in Turkey: The Case of Niğde Province. Journal of Ciência Rural 48(8): 1-9.

Birama, B. C., dan Nurkhin, A. 2017. Peran Efikasi Diri Dalam Memediasi Pengaruh Perencanaan Karier Dan Lingkungan Teman Sebaya Terhadap Minat Melanjutkan Pendidikan Ke Perguruan Tinggi Siswa SMA Negeri 2 Slawi. Economic Education Analysis Journal 6(1): 109-119.

Budiati, Indah. 2014. Implikasi Minat Siswa Dalam Pengelolaan Pertanian Terhadap Keberlanjutan Minat Bertani Di Wilayah Kecamatan Parongpong (Studi Kasus Di SMAN 1 Parongpong). 2014. Jurnal Pendidikan Ilmu Sosial (JPIS) 23(2): 103-107.

Daharnis dan Ardi, Z. 2016. The Compatibility Student Choice Of University Majoring: A Preliminary Studies. Guidena-Journal of Guidance and Counseling 6(1): 101-109.

Ekpo, T.E. dan Ajake, U.E. 2013. Family Socio-Economic Status and Delinquency among Senior Secondary School Students in Calabar South, Cross River State, Nigeria. American International Journal of Contemporary Research 3(4): 83-88. 
Fitriani, Khoerunisa. 2014. Pengaruh Motivasi, Prestasi Belajar, Status Sosial Ekonomi Orang Tua Dan Lingkungan Sekolah Terhadap Minat Melanjutkan Pendidikan Ke Perguruan Tinggi Pada Siswa Kelas XII Akuntansi SMK Negeri 1 Kendal. Economic Education Analysis Journal (EEAJ). 3(1): 152-159.

Hambali, Ginanjar. 2017. Menciptakan Petani Masa Depan: Strategi Promosi Mengembangkan Pendidikan Pertanian. Jurnal Scientium 6(2): 126-182.

Hron, J., Macák, T. dan Huml, J. 2009. Design of the Diversification Classifier for Agricultural Entrepreneurs Activities. Agricultural Economics. 55(12): 565-570.

Indriyanti, N., Siswandari, dan Ivada, E. 2013. Faktor-Faktor Yang Memengaruhi Minat Melanjutkan Pendidikan Ke Perguruan Tinggi Pada Siswa Kelas XII Akuntansi SMK Negeri 6 Surakarta Tahun 2013. Jurnal Pedidikan Ekonomi UNS. 1(2): 1-10.

Kan, A., Kan, M., Hasan Gökhan Dogan, H. G., Tosun, F., Ucum, I., dan Solmaz, C. 2018. Evaluation Of Young Farmers Project Support Program In Terms Of Agri-Entrepreneurship In Turkey. Pakistan Journal of Agricultural Science. 55(4): 1021-1031.

Kharisma, N. dan Latifah, L. 2015. Pengaruh Motivasi, Prestasi Belajar, Status Sosial Ekonomi Orang Tua Dan Lingkungan Teman Sebaya Terhadap Minat Melanjutkan Pendidikan Ke Perguruan Tinggi Pada Siswa Kelas XII Kompetensi Keahlian Akuntansi Di SMK Negeri Se Kota Semarang Tahun Ajaran 2014/2015. Economic Education Analysis Journal 4(3): 833846.

Koech, J., Bitok J., Rutto, D., Koech, S., Okoth, J. O., Korir, B., dan Ngala, H. 20106. Factors Influencing Career Choice Among Undergraduate Students in Public Universities in Kenya: A Case Study of University of Eldoret. International Journal of Contemporary Applied Sciences 3(2): 5063.

Kontogeorgos, A. Tselempis D., and Karipidis P. 2014. Young Farmers' Perceived Service Quality of the Greek Ministry of Agriculture: A SERVQUAL Approach. Agricultural Economics Review (in press).

Koutsou, S., and Partalidou, M. 2012. Pursuing Knowledge and Innovation through Collective Actions. The Case of Young Farmers in Greece. The Journal of Agricultural Education and Extension 8(5): 445-460.

Mc Greevy, S. R., Kobayashi, M., dan Tanaka, K. 2018. Agrarian Pathways for the Next Generation of Japanese Farmers. Canadian Journal of Development Studies 40(2): 1-19.

Mukembo, S. C., Edwards, M. C., Ramsey, J. W., and Henneberry, S. R. 2015. Intentions of Young Farmers Club (YFC) Members to Pursue Career Preparation in Agriculture: The Case of Uganda. Journal of Agricultural Education 56(3): 16-34.

66 | Kadhung P; Suryani N; Adietya Muhammad; Penguatan Sistem... 
Mukembo, S. C., Edwards, M. C., Ramsey, J. W., and Henneberry, S. R. 2014. Attracting Youth to Agriculture: The Career Interests of Young Farmers Club Members in Uganda. Journal of Agricultural Education 55(5): 155-172.

Nalim. 2012. Analisis Faktor Yang Memengaruhi Mahasiswa Dalam Memilih Program Studi Pendidikan Bahasa Arab Stain Pekalongan. Forum Tarbiyah 10(2): 214-235.

Oizumi. 2013. Aging in Asia. Tokyo: Oriental Life Insurance Cultural Development Center.

Purnamasari, I. dan Hayati, M. N. 2018. Analisis Deskriptif Pada Faktor-Faktor Yang Mempengaruhi Minat Siswa Untuk Melanjutkan Pendidikan Ke Tingkat Perguruan Tinggi. Statistika 6(2): 114-118.

Rahmawatiningsih, Ayu, I Made Angga Prayoga, Ni Putu Widyami Yanthi dan I Gede Rai Maya Temaja. 2010. Pemberian Ekstrakurikuler Pertanian Pada Siswa SD Di Desa Gunaksa Kabupaten Klungkung, Bali. Jurnal IPTEKMA 2(01): 30-34.

Rigg, J., Salamanca, A., and Parnwell, M. 2012. Joining the Dots of Agrarian Change in Asia: A 25 Year View from Thailand. World Development 40(7): 1469-1481.

Seleksi Nasional Masuk Perguruan Tinggi Negeri. 2018. Daftar Perguruan Tinggi dan Program Studi yang Ditawarkan. https://web.snmptn.ac.id/ptn/355/15529. Diakses pada 17 Desember 2018.

Setiawan, R. 2018. Minat Siswa SMK Melanjutkan Studi Ke Perguruan Tinggi Pada Siswa Kelas XII Program studi Akuntansi SMK Dharma Putera Banjarmasin. JIEB: Jurnal Ilmiah Ekonomi Bisnis 4(2): 176-190.

Shanka, T., Quintal, V., Taylor, R. 2005. Factors Influencing International Students' Choice of an Education Destination-A Correspondence Analysis. Journal of Marketing for Higher Education 15(2): 31-46.

Simpach, O., and Pechrova, M. 2014. The Impact of Population Development on the Sustainability of the Rural Regions. Proceeding of Agrarian perspectives XXIII - The Community led Rural Development 10(3529): 129136.

Toor, M. A. 1991. Need of Agricultural Education for Young Farmers in Faisalabad Tehsil. Pak. J. Agri. Sci. 28(1): 48-49.

United Nations Development Programme. 2018. Human Development Indices and Indicators: 2018 Statistical Update. http://hdr.undp.org/sites/default/files/2018_human_development_statistical_ update.pdf. Diakses pada 17 Desember 2018.

Verhees, F. J. H. M., Kuipers, A., dan Klopcic, M. 2011. Entrepreneurial Proclivity and Farm Performance: The Cases of Dutch and Slovenian Farmers. International Journal of Entrepreneurship and Innovation 12(3): 169-177. 